\title{
Losses in the mechanized harvest of sugarcane as a function of working speed and rotation of the primary extractor
}

\section{Perdas na colheita mecanizada de cana-de-açúcar em função da velocidade de trabalho e da rotação do extrator primário}

\author{
Murilo Battistuzzi MARTINS ${ }^{1}$; João Vitor Paulo TESTA²; Fernanda Scaranello DRUDI; \\ Jefferson SANDI'; Kléber Pereira LANÇAS ${ }^{4}$ \\ ${ }^{1}$ Autor para correspondência: Mestre em agronomia (Energia na Agricultura); Faculdade de Ciências Agronômicas/Botucatu - \\ SP; Departamento de Engenharia Rural; Rua José Barbosa de Barros, no 1780; mbm_martins@hotmail.com \\ ${ }^{2}$ Mestre em agronomia (Energia na Agricultura); Faculdade de Ciências Agronômicas/Botucatu - SP: \\ joaovitortesta@outlook.com; jffsandi@gmail.com \\ ${ }^{3}$ Engenheira Agrônoma; Centro Universitário Moura Lacerda; fernandadrudi@gmail.com \\ ${ }^{4}$ Professor Titular Departamento de Engenharia Rural; Faculdade de Ciências Agronômicas/Botucatu - SP; \\ kplancas@fca.unesp.br
}

Recebido em: 22-08-2016; Aceito em: 24-02-2017

\begin{abstract}
Sugarcane (Saccharum spp.) stands out as one of the main crops of Brazilian agribusiness. Currently, the crop harvesting process is predominantly mechanized. The objective was to evaluate the losses and impurities in the mechanized harvest of sugarcane as a function of working speed and rotation of the primary extractor. The experiment was conducted in a sugarcane harvested without previous burning, using the variety CTC 15 in its first cutting stage, classified as upright. The row spacing was $1.5 \mathrm{~m}$ and the average crop yield was $92.5 \mathrm{Mg} \mathrm{ha}^{-1}$. A single-row harvester was used, operating at three working speeds, being V1 $\left(3.0 \mathrm{~km} \mathrm{~h}^{-1}\right), \mathrm{V} 2\left(5.0 \mathrm{~km} \mathrm{~h}^{-1}\right)$ and V3 $\left(7.0 \mathrm{~km} \mathrm{~h}^{-1}\right)$. Two rotations of the primary extractor were used, R1 $(700 \mathrm{rpm})$ and R2 (1000 rpm). In the experiment, the loss of raw material and the vegetable impurities were evaluated shortly after the harvester went through the experimental area. With the highest rotation of the primary extractor, there were average levels of vegetable impurities (4 to $6 \%$ ), and with the lowest rotation, there were high levels (>7\%). Levels for plant losses were low $(<2.5 \%)$ for all evaluated treatments.
\end{abstract}

Additional keywords: evaluation; mechanization; performance; quality.

\section{Resumo}

A cana-de-açúcar (Saccharum spp.) destaca-se como uma das principais culturas do agronegócio brasileiro. Atualmente, o processo de colheita da cultura é, predominantemente, realizado de forma mecanizada. Objetivouse avaliar as perdas e as impurezas vegetais na colheita mecanizada de cana-de-açúcar em função da velocidade de trabalho e da rotação do extrator primário. O experimento foi conduzido em um canavial colhido sem queima prévia, sendo utilizada a variedade CTC 15, em seu primeiro estágio de corte e com porte classificado como ereto. O espaçamento entre fileiras foi de $1,5 \mathrm{~m}$, e a produtividade média da cultura, de $92,5 \mathrm{Mg} \mathrm{ha}^{-1}$. A colhedora utilizada foi de uma linha, operando em três velocidades de trabalho, sendo V1 $\left(3,0 \mathrm{~km} \mathrm{~h}^{-1}\right), \mathrm{V} 2$ $\left(5,0 \mathrm{~km} \mathrm{~h}^{-1}\right)$ e V3 $\left(7,0 \mathrm{~km} \mathrm{~h}^{-1}\right)$. Foram utilizadas duas rotações do extrator primário, sendo a R1 de $700 \mathrm{rpm}$ e a R2 de $1.000 \mathrm{rpm}$. No experimento, foram avaliadas a perda de matéria-prima e as impurezas vegetais logo após a passagem da colhedora na área experimental. As impurezas vegetais com a maior rotação do extrator primário apresentaram níveis médios (4 a 6\%), e a menor rotação do extrator primário, níveis altos (> 7\%). Os níveis para perdas vegetais foram baixos $(<2,5 \%)$ para todos os tratamentos avaliados.

Palavras-chave adicionais: avaliação; desempenho; mecanização; qualidade.

\section{Introduction}

The sugarcane is a monocotyledon of the Poaceae family, which has a high photosynthetic rate. This crop has a large size and is semi-perennial, forming clumps with fibrous stems and rich in sucrose. The propagation is vegetative, using stems, billet or seedlings whose buds sprout when they find favorable climatic conditions. After harvesting, the buds of the rhizomes sprout, giving rise to a new clump (Silva et

\section{al., 2015).}

Sugarcane cultivation has a great importance in the Brazilian economy since the colonial period (Carvalho et al., 2013), being the main raw material for the manufacture of products such as sugar and ethanol, and by-products such as bagasse (co-generation of electric power), filter cake and vinasse.

Of the three types of harvesting systems (manual, semi-mechanized and mechanized) for sugarcane cultivation, mechanization is the system that 
has replaced manual harvesting in the sugarcane sector to supply labor shortages, reduce the environmental impact caused by burning straw, increase the operational efficiency and modernize the sector (Giachini et al., 2016).

The losses of sugarcane raw material in cane fields occur independently of the harvesting system used during harvest. According to Neves (2015), the losses represent all the industrializable variations of sugarcane that remain in the field during the harvest and can be identified as visible, considering the whole stems and their fractions, billet and stumps resulting from the basal cut of the sugarcane harvester. The increase of raw material losses is influenced by the increase of the working speed of the harvester, with these losses being unacceptable economically (Ramos et al., 2014).

The impurities are classified as any material that is together with the raw material harvested and that is not industrializable, which may be both of vegetable origin, i.e., originating from the plant (green leaves, straw, heart of palm, roots and dry stems), and of mineral origin, which corresponds to the amount of soil taken along with the wheel load (Alonso, 2006). When taken to the industry together with the harvested material, vegetable impurities hinder the extraction process of sugarcane juice in the mills, the broth clarification and the formation of sugar crystals, reducing the color quality of the sugar produced (Cassia et al., 2015).

Knowing the causes of losses and impurities in the harvest facilitates the process for necessary corrections aiming to reduce them in the cane fields. Some of the factors are the uses of the harvester's working speed and rotation of the primary extractor suitable for the productivity of sugarcane, besides the synchronism of the speed and distance of the harvester with transhipment, regulation and state of the active organs of the harvester, the training and technological qualification for operators and the soil preparation of the area in a suitable way for the mechanized harvest (Neves, 2015).

Therefore, the objective was to evaluate the losses and impurities in the mechanized harvest of sugarcane at three working speeds of the sugarcane harvester and two rotations of the primary extractor.

\section{Material and methods}

The experiment was carried out at the Pederneiras plant, belonging to the Zambianco group, located in the municipality of Tietê, state of São Paulo, with the geographical coordinates 22 $2^{\circ} 58^{\prime} 09^{\prime \prime}$ South latitude and $47^{\circ} 43^{\prime} 12^{\prime \prime}$ West longitude.

The experimental area had the variety CTC15, in an area of 18.66 ha. The spacing between rows was 1.5 meters and the terrain had an average slope of $6 \%$, being thus suitable for mechanized harvesting. During the accomplishment of the cultivation in the experimental area, a ground leveling operation (break-back) was performed in between lines. Harvesting occurred without previous burning of the cane field and the average yield of the area was $92.5 \mathrm{Mg} \mathrm{ha}^{-1}$.

Throughout the experiment, the same sugarcane harvester was used, brand CASE A8800, according to the characteristics in Table 1.

Table 1 - Characteristics of the harvester used.

\begin{tabular}{ll}
\hline Year of manufacture & 2010 \\
Hour meter & 6,017 hours \\
Rated Power & $243 \mathrm{~kW}(330 \mathrm{hp})$ \\
Tip cutter & Bidirectional separating \\
Shipping mass & drum \\
Wheel & $18,300 \mathrm{~kg}$ \\
\hline
\end{tabular}

Three harvester working speeds were selected, being 3.0 (V1), 5.0 (V2) and $7.0 \mathrm{~km} \mathrm{~h}^{-1}$ (V3). Two rotations of the primary extractor of the machine were used, $700 \mathrm{rpm}$ (R1) and $1000 \mathrm{rpm}$ (R2). The treatments were conducted with six replicates, totaling 36 plots. The area corresponding to the plots was obtained from bands of $100 \mathrm{~m}$ of harvest length. The design was completely randomized.

The determination of the working speed was performed by means of the time spent to go through each plot. To determine the distance of each plot and the time spent in the displacement, a Garmin GPS model MAP 60csx was used. The average speed was obtained by Equation 1:

Wsp $=\frac{\mathrm{L}}{\Delta \mathrm{t}} \times 3.6$

Wherein: Wsp is the working speed of the harvester $\left(\mathrm{km} \mathrm{h}^{-1}\right), \mathrm{L}$ is the length of the experimental plot $(\mathrm{m}), \Delta \mathrm{t}$ is the time spent to go through the experimental plot (s) and 3.6 is the conversion factor.

To determine the visible losses of raw material, the methodology proposed by Benedini et al. (2009) was used, where losses are measured directly by demarcating an area immediately after harvesting and performing the manual collection of all fractions that were not collected (fractions of billet that were shattered, whole pieces or crushed/shredded pieces of sugarcane, pieces of sugarcane attached to the pointers, whole billet thrown out of the transhipment vehicle, and stumps above $5 \mathrm{~cm}$ left behind by deficiency in the basal cut) (Table 2). The area of the plot sampled was approximately $10 \mathrm{~m}^{2}$, covering two lines of sugarcane with $3.0 \mathrm{~m}$ in width and $3.3 \mathrm{~m}$ in row length.

Table 2 - Classification of raw material losses.

\begin{tabular}{lc}
\hline Level of losses & Percentage of losses (\%) \\
\hline Low & $<2.5$ \\
Medium & 2.5 a 4.5 \\
High & $>4.5$ \\
\hline
\end{tabular}

Source: BENEDINI et al., (2009).

After separating the material found, the mass of each material collected was measured using a 
portable scale with a reading capacity of $25 \mathrm{~kg}$ and an accuracy of 10 grams. The losses were calculated absolutely $\left(\mathrm{Mg} \mathrm{ha}^{-1}\right)$, multiplying the final value in weight per 1,000 . For the percentage value, this value was divided by productivity plus the value of losses, according to Equation 2.

$\mathrm{Pc}(\%)=\frac{\mathrm{PF}}{\mathrm{P}+\mathrm{PF}} 100$

Wherein: $\mathrm{Pc}$ is the percentage of losses in the field $(\%), \mathrm{PF}$ are the losses in the field $\left(\mathrm{Mg} \mathrm{ha}^{-1}\right), \mathrm{P}$ is the productivity of the sugarcane field $\left(\mathrm{Mg} \mathrm{ha}^{-1}\right)$ and 100 is the conversion factor

To evaluate the quality of the raw material harvested by the harvester, samples of the harvested material that would be deposited in the transhipment of sugarcane were taken, using plastic bags to collect the material, in each repetition. The samples were removed after the secondary extractor, and they passed through all cleaning systems of the harvester, i.e., primary extractor and secondary extractor, allowing the evaluation of the actual amount of strange plant material in relation to the harvested material.

After the material was collected, the samples were separated into fractions for the determination of vegetable impurity, being: billet, pointers, leaves and straws, roots and total. These fractions were measured with portable scale, and the percentages of each item were determined in the total sample (Figure 1). The classification of plant impurities was performed according to Benedini et al. (2009) (Table 3).

Table 3 - Classification of vegetable impurities.

\begin{tabular}{lc}
\hline $\begin{array}{l}\text { Classification of } \\
\text { vegetable impurities }\end{array}$ & $\begin{array}{c}\text { Percentage of vegetable } \\
\text { impurities }(\%)\end{array}$ \\
\hline Low & $<3$ \\
Medium & 4 a 6 \\
High & $>7$ \\
\hline
\end{tabular}

Source: Benedini et al., (2009).

Statistical analysis was performed first by the $\mathrm{F}$ test and, when significant at least with $5 \%$ probability, the means were compared by Tukey test at $5 \%$ probability.

\section{Results and discussions}

Since there was no interaction between the working speed of the harvester and the rotation of the primary extractor for the fractions, the mean values of the treatments performed in the test were used (Table 4).

Table 42 - Mean of vegetable losses in the raw material.

\begin{tabular}{lccc}
\hline \multirow{2}{*}{ Working speed $\left(\mathrm{km} \mathrm{h}^{-1}\right)$} & \multicolumn{2}{c}{ Rotation of the primary extractor $(\mathrm{rpm})$} & \multirow{2}{*}{ Mean $(\%)$} \\
\cline { 2 - 3 } & $\mathrm{R} 1$ & $\mathrm{R} 2$ & \\
\hline S1 & 1.2 & 1.3 & $1.2 \mathrm{~B}$ \\
S2 & 1.4 & 1.7 & $1.6 \mathrm{AB}$ \\
S3 & 2.0 & 2.3 & $2.1 \mathrm{~A}$ \\
Mean (\%) & $1.5 \mathrm{a}$ & $1.8 \mathrm{a}$ & \\
\hline \multicolumn{2}{c}{ Test $\mathrm{F}$ (speed) } & \multicolumn{2}{c}{ Analysis of variance } \\
\hline \multicolumn{1}{c}{ 5.80 } & Test $\mathrm{F}$ (rotation) & Test $\mathrm{F}$ (interaction) & $\mathrm{CV}(\%)$ \\
\hline
\end{tabular}

Means followed by equal letters, upper case in column and lower case in line do not differ by Tukey test ( $\alpha=5 \%)$; C.V. - Coefficient of variation; ${ }^{*}$ significant at $5 \%$ probability; NS - not significant.

As the speed of the harvester increased, a higher plant loss occurred in all evaluated treatments, with $\mathrm{V} 1$ presenting a lower value of plant loss when compared to V3; on the other hand, V2 $\left(5.0 \mathrm{~km} \mathrm{~h}^{-1}\right)$ did not differ statistically from the other speeds (Table 4). When the primary extractor rotations were analyzed, there was no difference.

With these results, it is possible to observe that for the plant losses, the variable speed has greater influence, as described by Ramos et al. (2014), where an increased working speed of the harvester resulted in increased losses of raw material. Similarly, Segato et al. (2011), when verifying the influence of increasing the sugarcane harvester's speed on plant losses, concluded that there is a relationship between these factors.
The values of this test are lower than those observed by Santos (2015), who, when testing double-row sugarcane harvesters, obtained values of 3 to $5 \%$ plant losses, a fact attributed to the number of rows in which the harvester collects plant material.

Giachini et al. (2016), evaluating an experiment of sugarcane losses during day and night harvests with similar sugarcane yield, obtained values of losses close to this test, of 1 to $2.2 \%$, but with different factors interfering. It must be considered that for this trial the increase in speed caused the greatest loss, yet for those authors, the harvest period influenced the loss, and the highest value was observed at night harvest. The authors attribute this value to the nonincidence of sunlight, which can make it difficult for the operator to visualize the process at the time of harvest, 
not noticing operating failures leading to greater loss.

The results found in this study disagreed with those observed by Neves et al. (2006), who stated that the poor performance of harvesters, expressed by the high rates of raw material losses, is not associated with the harvester's working speed.

With the values obtained in this work, it was verified that the percentage of losses, according to
Benedini et al. (2009), would be classified as low for all treatments, since it was less than $2.5 \%$.

As with plant losses, because there was no interaction between the working speed and the rotation of the primary extractor, only the mean values of the vegetable impurities were used, and not the fractions separately, which did not differ statistically (Table 5).

Tabela 5 - Mean of vegetable impurities in the raw material.

\begin{tabular}{|c|c|c|c|}
\hline \multirow{2}{*}{ Working speed $\left(\mathrm{km} \mathrm{h}^{-1}\right)$} & \multicolumn{2}{|c|}{ Rotation of the primary extractor (rpm) } & \multirow{2}{*}{ Mean (\%) } \\
\hline & $\mathrm{R} 1$ & $\mathrm{R} 2$ & \\
\hline S1 & 7.0 & 6.9 & $7.0 \mathrm{~A}$ \\
\hline S2 & 7.6 & 5.5 & $6.6 \mathrm{~A}$ \\
\hline S3 & 7.3 & 5.5 & $6.4 \mathrm{~A}$ \\
\hline Mean (\%) & $7.3 \mathrm{a}$ & $6.0 \mathrm{~b}$ & \\
\hline \multicolumn{4}{|c|}{ Analysis of variance } \\
\hline Test F (speed) & Test $F$ (rotation) & Test F (interaction) & CV $(\%)$ \\
\hline $0.29^{\mathrm{NS}}$ & $4.98^{*}$ & $0.96^{N S}$ & 23.74 \\
\hline
\end{tabular}

Means followed by equal letters, upper case in column and lower case in line do not differ by Tukey test $(\alpha=5 \%)$; C.V. - Coefficient of variation; * significant at $5 \%$ probability; NS - not significant.

The working speed of the harvester did not show difference for the average of impurities, however for the means of the rotations of the extractors there was difference, and the highest value of vegetable impurities was found in the rotation R1 (700 rpm), the smaller being verified in R2 (1000 rpm), demonstrating the influence of the primary extractor's rotation on the cleaning of sugarcane (Table 5). Notwithstanding, Ramos et al. (2014), evaluating the quality of mechanized sugarcane harvesting, describes that the vegetable impurities were not influenced when there was a change in the working speed or in the rotation of the harvester's motor.

According to the classification of Benedini et al. (2009), the values found in this work for the treatments V1R2; V2R2; V3R2 present average levels of vegetable impurities, yet the treatments V1R1; V2R1; V3R1 have high levels of plant impurities.

The results of this work, from 5.5 to $7.6 \%$, are lower than those of Schmidt Junior (2011), who obtained values between 10 and $15 \%$ in a test with two harvesters, where a prototype model, which may need to be improved, generated the highest value of impurity. Nonetheless, the author attributes this result to the working speed of the harvester, differing from the variable of this study.

\section{Conclusions} treatments.

Plant losses are low $(<2.5 \%)$ for the evaluated

The higher the working speed, the greater the plant loss. Plant losses are not affected by the rotation of the primary extractor.

The highest rotation of the primary extractor (1000 rpm) shows an average level (4 to $6 \%$ ) of vegetable impurities and the lowest rotation of the primary extractor (700 rpm) shows high levels (> 7\%).

The higher the rotation of the primary extractor, the lesser the impurities. Impurities values are not affected by speed.

\section{References}

Alonso O (2006) Estratégias para melhorar a qualidade da cana-de-açúcar para a indústria. In: Segato SV, Pinto AS, Jendiroba E, Nóbrega JCM (ed) Atualização em produção de cana-de-açúcar, Piracicaba: CP 2. p.361-367.

Benedini MS, Brod FPR, Perticarrari JG (2009) Perdas e impurezas vegetais e minerais na colheita mecanizada. CTC (Boletim técnico).

Carvalho LC, Bueno RCOF, Carvalho MC, Favoreto AL, Godoy AF (2013) Cana-de-açúcar e álcool combustível: histórico, sustentabilidade e segurança energética. Enciclopédia Biosfera, Centro Científico Conhecer 9(16):530-543.

Cassia MT, Franzé RV, Pizzinatto AAS (2015) Controle de qualidade de operações - Resultados de operações em unidades sucroenergéticas. In: In: Belardo GC, Cassia MT, Silva RP (ed) Processos agrícolas e mecanização da cana-de-açúcar, SBEA. p. 393-413.

Giachini CF, Ramos CRG, Lyra GA, Gamero CA, Lanças KP (2016) Consumo de combustível e perdas de cana-de-açúcar durante a colheita diurna e noturna. Energia na Agricultura 31(1):10-16.

Neves JLM (2015) Avaliação da colheita mecanizada Avaliações de perdas quantitativas na colheita de cana-de-açúcar. In: Belardo GC, Cassia MT, Silva RP (ed) Processos agrícolas e mecanização da cana-deaçúcar, SBEA. p. 367-373.

Neves JLM, Magalhães PSG, Moraes EE, Araújo FVM (2006) Avaliação de perdas invisíveis na colheita mecanizada em dois fluxos de massa de cana-deaçúcar. Engenharia Agrícola 26(3):787-94. 
Ramos CRG, Lanças KP, Lyra GA, Millani TM (2014) Qualidade da colheita mecanizada de cana-de-açúcar em função da velocidade de deslocamento e rotação do motor da colhedora. Energia na Agricultura 29(2):87-94.

Santos NB, Fernandes HC, Gadanha Júnior CD (2015) Economic impact of sugarcane (Saccharum spp.) loss in mechanical harvesting. Científica 43(1):16-21.

Schmidt Junior JC (2011) Avaliação do desempenho efetivo de colhedora de cana-de-açúcar (Saccharum spp.). Escola Superior de Agricultura "Luiz de Queiroz", Universidade de São Paulo (Dissertação de Mestrado em Máquinas agrícolas).
Segato SV, Daher F (2011) Perdas visíveis na colheita mecanizada de cana-de-açúcar crua sob velocidades de deslocamento da colhedora. Nucleus, 8(1): 315326.

Silva FC da, Alves BJR, Freitas PL de (2015) Sistema de produção mecanizada da cana-de-açúcar integrada à produção de energia e alimentos. EMBRAPA. 586p. 